Anna Małdrzykowska SAC

Warszawa

\title{
IMPLIKACJE PEDAGOGICZNE REALIZMU FILOZOFICZNEGO SZKOŁY LUBELSKIEJ
}

The pedagogical implications of the Lublin School's philosophical realism

Su m mary: This article focuses on the pedagogical implications of the Lublin School's philosophical realism. The author examines the mediation of pedagogical issues in realism, and points out the language that realism can lend to pedagogy and thereby help to give a definition to such notions as upbringing, educator and student. Thus the realism of the Lublin School is presented as a rich source of pedagogical inspiration that is worth exploring.

Keywords: realism, Lublin School, pedagogy, implications, upbringing, person, educator, student, language

Temat wystąpienia generuje pytania o rozumienie tytułowych wyrażeń: realizm filozoficzny, Szkoła Lubelska, pedagogika i implikacja. One też wyznaczają strukturę mojego wystąpienia. Mając świadomość wielowątkowości i obszerności podejmowanej problematyki już na wstępie warto zauważyć, że wyodrębnione implikacje pedagogiczne wyznaczają ogólny obszar dalszych poszukiwań, które mogą stać się cenną inspiracją, jak korzystać z realizmu filozoficznego Szkoły Lubelskiej we wspólnej dla filozofii i pedagogiki - refleksji nad światem osób i rzeczy.

$\mathrm{W}$ tej perspektywie zasadniczy problem tego wystąpienia przedstawia się następująco: co z realizmu filozoficznego szkoły lubelskiej wynika dla pedagogiki? Czy i jakie stwarza możliwości odczytania i recepcji szeroko pojętej działalności wychowawczej? Co sugeruje rozwijanej obecnie teorii i praktyce pedagogicznej? Tak postawiony cel pozwoli odpowiedzieć na szereg konkretnych pytań: czym według realizmu filozoficznego szkoły lubelskiej jest wychowanie? Kim jest wychowawca, pedagog i wychowanek? Pytania te, rzecz jasna, pozostają w ścisłym związku z ogólnym pytaniem o człowieka, jego miejsce w świecie i stosunek do rzeczywistości.

Wyrażenia: „realizm filozoficzny”, „metafizyka”, „teoria bytu”, „ontologia” traktuję jako synonimy na określenie filozofii, „w której dąży się do rozumiejącego poznania konkretnie bytujących rzeczy poprzez wskazanie na ostateczne przyczyny 
ich istnienia i działania"'. Za Andrzejem Maryniarczykiem realizm rozumiem jako „pogląd, na podstawie którego uznajemy istnienie przedmiotów zewnętrznych względem podmiotu poznającego. Przyjmuję też, że świat dany nam w doświadczeniu (bezpośrednim) istnieje realnie, czyli niezależnie od aktów naszej świadomości”2. Zajmujemy się więc wszystkim co jest, nie zakładając wcześniej jakiejś teorii tego przedmiotu³. Przedmiot metafizyki wyróżnia się więc realizmem, uniwersalizmem, neutralizmem. Uznanie prymatu istnienia w bycie gwarantuje realizm poznawczy, który charakteryzuje się poznaniem przedmiotowym (czytania z rzeczy dorzecznym), przyczynowym, prawdziwościowym i ostatecznym oraz transcendentalnym, analogicznym i rozumiejącym. „Nie jest on zakładany a priori, lecz jest wynikiem odczytywania rzeczywistości, której istnienie ma pierwszeństwo przed działaniem poznawczym i myślowym"4. A więc u progu wyjścia poznania filozoficznego jest to, co realnie istnieje. Rzeczywistość jest odczytywana kontemplowana (moglibyśmy powiedzieć), a nie kreowana.

Lubelską szkołę filozoficzną przyjmuję natomiast w sensie ścisłym jako grupę filozofów pracujących w pewnym porozumieniu oraz realizujących wspólny program i posiadających zbieżny warsztat metodyczny. Mam tu między innymi na myśli takie osobowości jak: J. Kalinowski, S. Swieżawski, M.A. Krąpiec, S. Kamiński, B.A. Stępień, A. Maryniarczyk i inni. Lubelska Szkoła Filozoficzna jest więc tym naturalnym miejscem rozwoju filozofii, której przedmiotem jest realnie istniejąca rzeczywistość; chcemy się jej przyjrzeć jako źródłu pedagogicznych implikacji.

Oczywiście zachowuję pamięć twórczego sporu o uzasadnienie realizmu w ramach szkoły, zamierzam go w pewnym stopniu uwzględnić, ponieważ temat domaga się tego w sposób szczególny. Przyjmując bowiem którą́ z proponowanych koncepcji wchodzących w spór, musimy być świadomi konsekwencji, jakie z niej wynikają. I tak również w perspektywie pedagogicznej będzie miało znaczenie, czy mamy do czynienia z bytem, czy też może z pojęciem bytu. Będzie się liczyło, czy metodę poznania realistycznego - wyznaczoną przez byt realnie istniejący, który jest jej przedmiotem oraz przez cel metafizyki (to jest wyjaśnienie i zrozumienie rzeczywistości) - będziemy rozumieli jako separację czy jako abstrakcję. Zależy mi więc, aby, zachowując „klimat” metafizyki, pójść w tych rozważaniach najwłaściwszą drogą, czyli taką, która jest zgodna z naturą rzeczy.

Pedagogikę rozumiem natomiast nie tylko jako naukę o wychowaniu, z wyraźnie wyodrębnionym przedmiotem badań i wypracowanymi metodami ${ }^{5}$, ale przede wszystkim jako „sztukę wychowania”. Chodzi więc zarówno o refleksję nad

\footnotetext{
${ }^{1}$ Andrzej Maryniarczyk, Zeszyty z metafizyki, t. I ( Lublin: Polskie Towarzystwo Tomasza z Akwinu 2001), 22.

${ }^{2}$ Tegoż, System metafizyki (Lublin: Redakcja Wydawnictw KUL 1991), 280-281.

${ }^{3}$ Zob. Maryniarczyk, Zeszyty, 24.

4 Tomasz Mioduszewski, Spór o realizm w lubelskiej szkole filozoficznej (Ząbki: APOSTOLICUM Wydawnictwo Księży Pallotynów Prowincji Chrystusa Króla 2013), 25.

${ }^{5}$ Por. Wincenty Okoń, Nowy Stownik Pedagogiczny (Warszawa: Wydawnictwo Akademickie „Żak” 1995), 207-208.
} 
wychowaniem, jak i zarazem praktykę wychowawczą. Pedagogika wyrosła na gruncie filozofii i nietrudno dostrzec ich naturalne powiązania. Poglądy na wychowanie pozostają w ścisłej relacji z filozoficznymi i ideowymi przesłankami swojej epoki. Nie dziwi więc potrzeba filozoficznej interpretacji zjawisk związanych $\mathrm{z}$ wychowaniem. Zwrot ku metafizyce wydaje się więc dziś niezbędny. Tym bardziej, że ona sama twardo trzymająca się realnie istniejącej rzeczywistości - jawi się jako wyraźnie odpowiadająca na zapotrzebowania pedagogiki miedzy innymi dlatego, że krytyczny stosunek do teoretycznych ujęć wychowania budzi potrzebę nowych rozwiązań odwołujących się do metodologicznych, antropologicznych, aksjologicznych i lingwistycznych osiągnięć realizmu. Bogatym źródłem jest więc zarówno jego strona metodologiczna, jak i treściowa; tym samym metafizyka przedstawia się nam jako ancilla scientiae, która może dostarczyć pedagogice narzędzi do rozumienia świata osób i rzeczy. Dzięki temu wyłoniły się już pierwsze zwiastuny interesujących nas implikacji (pojęcie to rozumiem tutaj, zgodnie z jego potocznym znaczeniem, jako wynikanie).

\section{Implikacje ogólne}

Zapośredniczenie kwestii pedagogicznych odbywa się w realizmie filozoficznym Szkoły Lubelskiej na kilku poziomach. Pierwszy dotyczy samej filozofii - czym jest i jaką pełni rolę wobec człowieka. Namysł nad filozofią i jej zasadniczym zadaniem dyktuje pytania o człowieka oraz otaczający go świat. Arystoteles powie, „że celem filozofii nie jest jakaś materialna korzyść czy określona użyteczność, lecz samo oglądanie prawdy dla niej samej”。. Ma więc ona charakter mądrościowy, a człowiek poszukujący prawdy to miłośnik mądrości - filozof. Jest on tym, który potrafi wskazać drogę życia. „Mówi [...] kim w rzeczywistości jest człowiek i co powinien czynić, aby prawdziwie być człowiekiem. Wskazuje [...] drogę. A tą drogą jest prawda" . Filozofia ma przede wszystkim opowiadać się i uznawać akt istnienia w bycie za najważniejszy czynnik bytowy, zajmować się rozumieniem i wyjaśnianiem realnego świata osób oraz rzeczy.

Na fakt, że lubelska szkoła realizmu filozoficznego postawiła w centrum uwagi egzystencjalną koncepcję bytu, akt istnienia jako najważniejszy czynnik bytowy, wpłynęło kilka czynników. Po pierwsze, wzrosło przekonanie, że dominująca w tym czasie filozofia świadomości jest niewystarczająca do opisu i wyjaśnienia ludzkiego bytu. Skompromitowana totalitaryzmami: faszyzmem i komunizmem, zagrażającymi samej istocie człowieczeństwa, została obarczona odpowiedzialnością za kryzys relacji międzyludzkich w tej postaci, jaki przyniosła rewolucja przemysłowa końca XIX wieku oraz pierwsza i druga wojna światowa.

\footnotetext{
${ }^{6}$ Maryniarczyk, Zeszyty, 10.

7 Benedykt XVI, Encyklika Spe Salvi Ojca Świętego Benedykta XVI do biskupów, prezbiterów i diakonów, do osób konsekrowanych i wszystkich wiernych świeckich o nadziei chrześcijańskiej (Kraków: Wydawnictwo AA 2007), 16.
} 
Wydaje się więc, że realizm filozoficzny Szkoły Lubelskiej jest od samego początku bardzo wyraźnie i świadomie zamierzoną reakcją na sytuację związaną z konkretnym czasem. Historycznie rzecz ujmując, konstytuowała się ona w wyniku takich wydarzeń, jak druga wojna światowa oraz komunistyczne czasy powojenne ze wszystkimi ich przyczynami, nie tylko o charakterze polityczno-społecznym, ale także, jeśli nie przede wszystkim, z najgłębszymi motywacjami kulturowymi i ideologicznymi. Wydarzenia te objawiły koniec dotychczasowego porządku świata, którego najbardziej dramatycznym przejawem był szeroko rozumiany kryzys społeczny. Warto wspomnieć, że największy rozwój szkoły przypada na lata 19591969. „Wtedy powstały najważniejsze prace i uformował się jej program”. ${ }^{8}$

Tymczasem cywilizacja dopracowała się nowego zjawiska - społeczeństwa masowego „znoszącego odrębność jednostki”; akcent przeniósł się z jednostki na kolektyw. „Jest masowa kultura i masowa histeria, masowe gusta (czy raczej brak gustu) i masowy obłęd, masowe zniewolenie i wreszcie - masowa zagłada. Jedynym bohaterem na scenie świata jest tłum, a główną cechą tego tłumu, tej masy, jest anonimowość, bezosobowość, brak tożsamości, brak twarzy. Jednostka zgubiła się w tym tłumie [...]. Stała się ona, żeby użyć określenia Gabriela Marcela, «bezosobowym anonimem w stanie cząstkowym»"10.

Kolejne zjawisko to rozwój techniki i nowych technologii. Chodzi tu o miejsce człowieka wobec nowych rzeczy, ale także o stosunki, które powstały na skutek ich działania lub przy ich współudziale. Człowiek nie może zapanować nad światem, który powstał dzięki niemu. Z jednej więc strony takie osiągnięcia, jak rozwój przemysłu, upowszechnienie i specjalizacja wiedzy, rosnąca ilość informacji, rozwój komunikacji, postępująca industrializacja i centralizacja kapitału oraz demokratyzacja życia społecznego dostarczają nowych możliwości życia i rozwoju. Z drugiej jednak strony nietrudno odnotować zanik zainteresowań metafizycznych. Człowiek nie zgłębia już istoty bytu, zamyka się na wielkie pytania dotyczące życia, Boga i samego siebie. Jego uwaga skierowana jest na produktywność, wydajność i przydatność. Ogranicza się do myślenia o rzeczach materialnych, o tym, czego można doświadczyć. Ograniczając człowieka do tego, co funkcjonalne i użytkowe oraz zjawiskowe i sprawdzalne, ogólny klimat kulturowo-filozoficzny prezentuje wizję świata pragmatycznego. Pokładając nadzieję jedynie w dziełach własnych rąk, człowiek został ostatecznie zredukowany do samego siebie jako miary wszystkiego. „Tendencja do uważania za prawdziwe tylko to, co można zweryfikować doświadczalnie, stanowi ograniczenie dla ludzkiego rozumu i jest przyczyną poważnej i dobrze dziś widocznej schizofrenii, która pozawala wspólistnieć racjonalizmowi i materializmowi, hipertechnologii i niepohamowanemu instynktowi" ${ }^{11}$.

${ }^{8}$ Mieczysław A. Krąpiec Teoria analogii bytu oraz tegoż, Realizm ludzkiego poznania, za: Mioduszewski, Spór, 15.

${ }^{9}$ Ryszard Kapuściński, Ten Inny (Kraków: SIW Znak 2006), 70.

${ }^{10}$ Tamże, 54 .

${ }^{11}$ Benedykt XVI, Święci w roku liturgicznym (Kraków: Espe 2011), 36. 
Taka filozofia potrzebuje więc, jako oczywistej konsekwencji zaistniałej sytuacji, odnowy w zakresie myślenia o samej sobie, człowieku i świecie.

\section{Struktura procesu wychowawczego}

Przechodząc już bezpośrednio do implikacji stricte pedagogicznych: realizm wyznacza nam pewną strukturę procesu wychowawczego; mamy świadomość złożoności tego procesu - jest tak różnorodny, jak różnorodni są ludzie. Po pierwsze, nie można wychowywać wszystkich w ten sam sposób. Po drugie, wyższy poziom oddziaływań wychowawczych nie może narodzić się w systemie nagród i kar. Taki behawioralny sposób oddziaływania na człowieka wydaje się niekompletny; kształtowanie okazuje się najbardziej skuteczne w środowisku wysokich wymagań i niskiego poziomu lęku' ${ }^{12}$.

Wydaje się więc, że pierwsza wskazówka, jakiej dostarczają nam filozofowie szkoły lubelskiej, brzmi następująco: proces wychowania to skutek doświadczenia realnej rzeczywistości, w której to doświadczenie przeżywający jest intelektualnie włączony, emocjonalnie zaangażowany i fizycznie obecny. Miejsca, w których dokonuje się wychowanie powinny charakteryzować się wyczuwalnością atmosfery oraz dynamiki twórczego czytania/oglądania świata. Realizm pozwala więc wychowankowi głębiej rozumieć świat, siebie, a także innych; inspiruje do odmiennego sposobu patrzenia. Uczenie się takiego myślenia związane jest nie tylko z doświadczeniem miejsca, w którym się ono odbywa, ale także - do czego wypadnie nam jeszcze wrócić - $\mathrm{z}$ językiem przekazu.

Wychowanie tym samym unika zawężenia tylko do edukacji, zdobywania wiedzy i informacji, a umożliwia pogłębienie przez uczenie czytania świata. Dzięki temu mamy szansę, by „wychowanie, na jakie [chyba] dziś [przede wszystkim] stać naszą cywilizację, [nie przypominało] wychowania, które sofiści sprzedawali ateńskim obywatelom. Cywilizacja ta, aby mogła funkcjonować, a niestety sprowadza się ona do funkcjonowania, potrzebuje sprawnych funkcjonariuszy [...]. Funkcjonariusze produkują specjalistyczne kursy [...]. Prowadzącym kursy nie chodzi o nauczanie ludzi tego, co dobre i o rozbudzenie ich wrażliwości na prawdę oraz na własny do niej stosunek, ale o wyrobienie w jednostkach zręczności w obrębie funkcji"13.

Chodzi więc o to, aby wychowanek otrzymał nie tylko pewną porcję wiedzy, lecz przede wszystkim doświadczenie realnego świata, w którym żyje na co dzień. Realizm uświadamia ważność pytania o to, jak uzyskiwać wiedzę i dostęp do niej, dostarcza więc wychowankowi stosownych pomocy, między innymi również w postaci poznania wolnego od jakichkolwiek założeń, teorii czy hipotez. Człowiek taki może zrozumieć, że rzeczy, wobec których się znajduje, są czymś zewnętrznym wobec niego. Realizm jest więc niełatwą propozycją dla wychowania: domaga się

\footnotetext{
${ }^{12}$ Zob. John L. Brown, Cerylle A. Moffet, The Hero's Journey: How Educators Can Transform Schools and Improve Learning (Alexandria Virginia: Association for Supervision and Curriculum Development 1991), 31.

${ }^{13}$ Stanisław Grygiel, W kręgu wiary i kultury (Kraków: Michalineum 1990), 201.
} 
nieustannego kontaktu z realną rzeczywistością, nie pozwala popadać wiluzje, wyobrażenia, stereotypy, schematy; nie kreuje świata, ale go ogląda.

Kolejna ważna sprawa (jak podpowiada mi moja skromna praktyka pedagogiczna) odnosi się do następującej kwestii: najbardziej skuteczne wychowanie jest możliwe tylko w środowisku, w którym motywacje są bardziej wewnętrzne, niż zewnętrzne. Zatem „poznanie metafizyczne, będąc «oglądaniem przedmiotów» w świetle prawdy, jest samo w sobie jak najbardziej [motywujące i jak najbardziej] cenne, gdyż rodzi «mądrość rozumu»"14. W takim środowisku wszyscy jego członkowie mają poczucie bycia częścią autentycznej, wychowującej wspólnoty.

Ostatnim założeniem procesu wychowawczego jest strategia. Skoro celem metafizyki - poznania realistycznego - jest rozumienie świata osób i rzeczy, jeśli chodzi o „poznanie pierwszych i ostatecznych przyczyn, których ślady odnajduje intelekt w rzeczach danych nam w doświadczeniu"15, to proces wychowania jest zorientowany na angażowanie wychowanka wasymilację taktyki związaną z tą wiedzą: jak ją zdobywać, kiedy używać posiadanych informacji, jak adoptować je do nowych sytuacji oraz jak zarządzać swoim własnym procesem wychowania. Ostatecznie poznanie to prowadzi przecież do jednego celu: „ad hominis perfectionem, quae est eius beatitudo - do doskonalenia czlowieka, które jest jego szczęściem"16 - powie św. Tomasz. A że przyszłość osoby ludzkiej jest nierozerwalnie związana $\mathrm{z}$ wychowaniem, to metafizyka odgrywa niezbywalną rolę w procesie wychowania człowieka jako osoby.

Tym samym kolejna lekcja realizmu filozoficznego, przed którą stajemy, brzmi: u podstaw wychowania musi być prawda o człowieku jako osobie. Samo pojęcie osoby pojawiło się najpierw w teatrze greckim. Persona (osoba) to tłumaczenie greckiego terminu prosopon i oznacza rolę, maskę w teatrze - pisał Wojciech Chudy. „Wiadomo jaką rolę odgrywał w kulturze greckiej teatr: zajmował tam miejsce centralne, był sztuka łączącą się z filozofią, ksztaltującą światopogląd i wyrażającą pewne teologiczne treści. Aktorzy występowali w trakcie przedstawień w maskach. Charakteryzowały one poszczególne postaci, jednak najistotniejsze było to, że pod maską występuje KTOŚ"17.

Św. Tomasz za Arystotelesem, a później korzystając z całej tradycji sporów nad chrystologią i trynitologią, zdefiniuje człowieka właśnie jako osobę. Jednak człowiek u św. Tomasza to już nie tylko arystotelesowski zoon logikon, ale osoba, to znaczy ,jednostkowy podmiot zdolny do wyłaniania świadomych i autonomicznych działań ludzkich, a więc byt, który może podejmować wolne i suwerenne akty decyzji. $\mathrm{Z}$ tego podmiotu, jak spod maski, wyłaniają się działania, w których i poprzez które ujawnia się prawda o człowieku jako osobie"18. Jako taki pozostaje więc

${ }^{14}$ Arystoteles, Zachęta do filozofii, przekł. Kazimierz Leśniak (Warszawa: Wydawnictwo Naukowe PWN 1988), 25.

${ }^{15}$ Por. Maryniarczyk, Zeszyty, 10.

${ }^{16} \mathrm{~S}$. Thomas Aquinatis, In XII libros metaphysicorum commentarium, proemium.

${ }^{17}$ Wojciech Chudy, „Oblicza personalizmu i ich konsekwencje”. Kwartalnik Filozoficzny 3 (1998), 63.

${ }^{18}$ Andrzej Maryniarczyk, Zeszyty z metafizyki, t. III (Lublin: Polskie Towarzystwo Tomasza z Akwinu 1999), 91. 
transcendentny wobec świata przyrody oraz zdolny do poznawania, miłości, wolności i religii. Wyróżnia się godnością, zupełnością oraz podmiotowością wobec prawa. Ta optyka zaprasza nas do odpowiedzi na pytania: kim jest wychowawca oraz kim jest wychowanek według realizmu filozoficznego szkoły lubelskiej?

\section{Wychowawca}

Kim jest zatem wychowawca według realizmu filozoficznego? Po pierwsze, to ktoś naprawdę obecny w życiu wychowanka. Po drugie, to człowiek - w myśl tego co powiedzieliśmy wcześniej - który w pewnym stopniu zawsze pozostaje równocześnie wychowankiem i wychowawcą w stosunku do siebie oraz w kontakcie z innymi. Chodzi tu również o doświadczenie tego, jak uczeń jest wychowywany oraz jak wychowuje nauczyciel. Wychowawca niejako jednocześnie doświadcza wychowywania ibycia wychowywanym. Jednocześnie zna skutki swojego oddziaływania na drugą osobę i to ona, a nie on sam, jest celem jego oddziaływań. To życie uczniów stanowi dla niego decydujący czynnik wychowawczego oddziaływania. Wychowawca jest na dwóch biegunach pedagogicznej rzeczywistości: swoim własnym i tym, który zajmuje wychowanek. Nasze spojrzenie kieruje się tu na nieustanną gotowość poznawania siebie oraz wychowanka, ukierunkowuje na sygnalizowane już zagadnienie samowychowania; zarządzanie własnym procesem wychowania, czyli świadomego, samodzielnego, wytrwałego i cierpliwego kierowania własnym rozwojem poprzez podejmowanie konkretnych działań w perspektywie wolnego poznania (czytania) oglądania świata. W myśl realizmu filozoficznego samowychowanie zmierza niejako do ukształtowania takiej wewnętrznej struktury osoby, dla której prawda - zawsze do odczytania - czyni ją wolną. Ethos wychowawcy, według realizmu, przedstawia go jako mistrza, przewodnika i nauczyciela, a nie „pompy”, która tłoczy w wychowanka wiedzę lub wyciska jego ukryte siły.

\section{Wychowanek jako podmiot wychowania}

Stajemy tu przed zagadnieniem człowieka wjego byciu i stawaniu się osobą. „Wychowanie zakłada dynamiczną strukturę człowieka, to znaczy jego stawanie się"19. Ta potrzeba/konieczność integralnego rozwoju człowieka zarówno w „bądź, jaki jesteś”, jak i „bądź, jaki powinieneś być” najpełniej realizuje się w relacji między wychowawcą i wychowankiem. Realizm uczy więc, że w relacji wychowawca wychowanek ważna jest afirmacja drugiego człowieka jako tego, który jest; kim ten ktoś jest. Należy więc wychowanka przyjąć za tego właśnie tego człowieka. Nie bez przyczyny słyszymy tu zarówno jeden z fundamentalnych tematów realizmu: uznanie prymatu istnienia w bycie, jak i biblijne echo imienia Boga: „Jestem Który Jestem”.

\footnotetext{
${ }^{19}$ Władysław Stróżewski, „O stawaniu się człowiekiem”, w: Człowiek - wychowanie - kultura, red. Fraciszek Adamski (Kraków: WAM 1993), 52.
} 
Antropologia realizmu filozoficznego proponuje pamiętać, że wychowanek to ktoś autonomiczny, samostanowiący, jedyny, zewnętrzny wobec mnie, inny w swojej swoistości, różny od pozostałych, to osoba, którą poznaję bez apriorycznych założeń. Nie chodzi więc o jakąś ideę dziecka, wyobrażenie jego indywidualności, ale o jego własną rzeczywistość, o przyjęcie go jako osoby.

Zapośredniczenie tematyki pedagogicznej w realizmie filozoficznym odnajdujemy również w idei wychowania podmiotowego. Podmiotowość oznacza, że każde ludzkie działanie jest działaniem czyimś, wypływającym z konkretnie usytuowanego źródła, jakim jest człowiek - działanie jest konsekwencją określonego istnienia. Myślę, że dziś szczególnie warto pójść drogą realizmu filozoficznego w tym spojrzeniu na człowieka jako osobę, aby - powiem to poetycko - oczyścić spojrzenie ze śniedzi uprzedzeń.

Tak rozumiane wychowanie jednostki jest jednocześnie wychowaniem całego społeczeństwa, gdyż jednostka bytuje w społeczeństwie, oddziałuje na innych, tworzy kulturę, ta zaś jest propedeutyką życia moralnego w sensie etycznym - poprzez realizację wartości rozpoznanych jako prawdziwe. Zatem wszelkie oddziaływanie wychowawcze oparte na osobowej relacji oraz konsekwentnym oglądaniu realnie istniejącego świata niesie w sobie zaczyn nadziei na poprawę kultury życia społecznego. Realizm uświadamia nam więc, że od rozumienia świata osób i rzeczy zależy moralne postępowanie człowieka oraz jego działalność naukowa i wytwórcza. Jeśli natomiast to rozumienie będzie błędne, odbije się złymi skutkami w moralności oraz kulturze.

Warto więc może jeszcze rzucić okiem na to, co realizm proponuje nam, jeśli chodzi o wychowawczą rolę wspólnoty (takiej jak rodzina, szkoła, grupa rówieśnicza, specyficzna grupa, jaką stanowią media) oraz rolę państwa i narodu w organizacji procesu wychowawczego. „Może nigdy, tak bardzo jak dzisiaj, wychowanie nie było nakazem życiowym i społecznym, który wymaga zajęcia stanowiska i zdecydowanej woli formowania dojrzałych osobowości. Może nigdy, tak jak dzisiaj, świat nie potrzebował ludzi, rodzin i wspólnot, które uczynią z wychowania racje swego bytu, które poświęca się wychowaniu, jako pierwszorzędnemu celowi, oddając bez zastrzeżeń swoje siły, szukając współpracy i pomocy podejmując próby i odnawiając w sposób twórczy i z poczuciem odpowiedzialności procesy wychowawcze" ${ }^{20}$.

W perspektywie wychowania opartej na optyce realizmu filozoficznego rodzina to szczególnie wyjątkowa sytuacja metafizyczna, która odsłania prawdziwą wielkość wychowania; to pierwsza i podstawowa wspólnota wychowująca. Jeśli podążyć za realizmem filozoficznym, trzeba przyjąć, że wychowanie w rodzinie rozpoczyna się już od łona matki i polega na obdarowaniu życiem, człowieczeństwem; to wspólistnienie i współdziałanie samodzielnych osób ${ }^{21}$. Szkoła powinna z kolei wyznaczać szeroki, otwarty horyzont, gdzie człowiek ma możliwość integralnego

\footnotetext{
${ }^{20}$ Jan Paweł II, „List Iuvenum Patris $w 100$ rocznicę śmierci św. Jana Bosko, Rzym, 31.01.1988”, w: Wychowanie w nauczaniu Jana Pawła II, red. Stanisław Urbański (Warszawa: Wyższa Szkoła Zarządzania i Przedsiębiorczości im. Bogdana Jańskiego 200o), 317.

${ }^{21}$ Zob. Jan Paweł II, List do Rodzin, nr 16.
} 
rozwoju w aspekcie edukacji, formacji aksjologicznej, wychowania religijnego (i innych) w warunkach wolności i poszanowania godności.

Grupa rówieśnicza to - idąc za myśleniem metafizycznym - lekcja życia w społeczeństwie, gdzie człowiek przeżywa pierwsze próby swojej wolności, konfrontuje własny system wartości, doświadcza relacji, indywidualności, uczy się dawać i przyjmować. Natomiast media - jako nośniki informacji i rozrywki o bardzo znaczącej roli w wychowaniu człowieka i społeczeństwa - wymagają wychowania do przekazu obiektywnego, wiernego z prawdą i poszanowaniem godności człowieka oraz (u odbiorcy) - wychowania do postawy dojrzałego i krytycznego korzystania ze środków społecznego przekazu.

Wreszcie naród (z jego własnym językiem, tradycją, kulturą, wartościami, organizacją prawną) oraz państwo są zobowiązane do troski o wychowanie poprzez organizację systemu wychowawczo-oświatowego, mają obowiązek zagwarantowania prawa do godziwego życia, pracy, porządku społecznego, ochrony, wolności wyznania, słowa, sumienia, wyboru kierunku kształcenia i stanu.

Wspólnoty, w których człowiek żyje i rozwija się, mają więc znaczący wpływ na jego wychowanie. Człowiek i wspólnota pozostają we wzajemnych odniesieniach i uwarunkowaniach. „Takie będą Rzeczypospolite jakie ich młodzieży chowanie” napisał kanclerz Jan Zamoyski w akcie fundacyjnym Akademii Zamojskiej.

\section{Język}

Realizm dostarcza również pedagogice narzędzi językowych. Posługując się językiem naturalnym w jego harmonii semantycznej, syntaktycznej i pragmatycznej, proponuje odpowiednie pojęcia, dzięki którym możemy opisać świat osób i rzeczy oraz prowadzić do ich zrozumienia. Pozwala także na rozumienie „takich rzeczywistości, jak: absolut, osoba, dusza, substancja, natura, dobro, prawda, piękno, działanie, doznawanie, i wiele innych" ${ }^{22}$.

Język wskazuje również na wartość wychowania aksjologicznego. Realizm chce nam powiedzieć, że wartości istnieją obiektywnie, zatem mogą być poznawane i oceniane przez człowieka. Stoją w służbie wychowania człowieka, wyrażającego swoją wolność oraz podmiotowość w czynie. Uwzględniają jego władze „intelekt wolę - uczucia z ich rolą w poznawaniu i czynieniu: prawdy - dobra - miłości”23. W tej perspektywie istotą wychowania jest pomoc wychowankowi w nawiązaniu relacji ztym co prawdziwe, słuszne, dobre, piękne, wartościowe. „Połączenie harmonii życia i harmonii wychowania”24.

Wartość tej językowej lekcji realizmu leży również między innymi w tym, że wiele pojęć obciążonych jest wieloznacznością, co może powodować fałszywe czy błędne nazywanie oraz rozumienie rzeczywistości, co w konsekwencji obraca się

\footnotetext{
${ }^{22}$ Maryniarczyk, Zeszyty, 16.

${ }^{23}$ Janina Kostkiewicz, Kierunki i koncepcje pedagogiki katolickiejw Polsce 1918 - 1939 (Kraków: Oficyna Wydawnicza „Impuls” 2013).

${ }^{24}$ Tamże.
} 
przeciwko samemu człowiekowi. Św. Bazyli mówi, że odpowiedzialnym za substytuowanie słów i ich znaczeń jest Szatan. „Diabeł jest to złodziej - pisze Święty - i kradnie słowa, nie po to, aby uczyć pobożności swych stronników, ale po to, aby oni, przyozdobiwszy słowami i myślami prawdy własną bezbożność, uczynili ją bardziej przekonywającą dla tłumu”"25. My znamy to zjawisko „podmieniania” choćby ze współczesnej debaty na tematy bioetyczne.

\section{Zakończenie}

Pedagogiczne propozycje realizmu filozoficznego szkoły lubelskiej koncentrują się na perspektywie człowieka jako osoby oraz akcentują jego konkretną egzystencję usytuowaną w określonej sytuacji społecznej i kulturowej. Autentyczność, wolność, zaangażowanie oraz podmiotowy, a także holistyczny charakter wychowania, realizującego się w otwarciu na transcendencję i dążącego ku samowychowaniu to, jak się wydaje, podstawowe kategorie wychowawczych postulatów realizmu. „Tam gdzie jest realizm filozoficzny, tam jest pedagogika"26.

Streszczenie: Treść wystąpienia koncentruje się wokół tematu implikacji pedagogicznych realizmu filozoficznego szkoły lubelskiej. Autorka, podejmując kwerendę co do zapośredniczenia kwestii pedagogicznych $w$ realizmie, wskazała na język, którego realizm może użyczyć pedagogice, a także zdefiniowała, czym jest proces wychowania oraz kim jest wychowawca i wychowanek. Tym samym realizm filozoficzny szkoły lubelskiej został ukazany jako bogate i godne eksploracji źródło inspiracji pedagogicznych.

Słowa kluczowe: realizm, szkoła lubelska, pedagogika, implikacje, proces wychowania, osoba, wychowawca, wychowanek, język

\section{Bibliografia}

Arystoteles. Zachęta do filozofii. Przekład Kazimierz Leśniak. Warszawa: Wydawnictwo Naukowe PWN, 1988. Benedykt XVI. Encyklika Spe Salvi Ojca Świętego Benedykta XVI do biskupów, prezbiterów i diakonów, do osób konsekrowanych iwszystkich wiernych świeckich onadziei chrześcijańskiej. Kraków: Wydawnictwo AA, 2007.

Benedykt XVI. Święci w roku liturgicznym. Kraków: Espe, 2011.

Brown, John L., Cerylle A. Moffet. The Hero's Journey: How Educators Can Transform Schools and Improve Learning. Alexandria Virginia: Association for Supervision and Curriculum Development, 1991.

Chudy, Wojciech. „Oblicza personalizmu i ich konsekwencje”. Kwartalnik Filozoficzny 3 (1998): 63-81.

Grygiel, Stanisław. W kręgu wiary i kultury. Kraków: Michalineum 1990.

\footnotetext{
${ }^{25}$ Za: Roman Bugaj, Hermetyzm (Wrocław-Warszawa-Kraków: Ossolineum 1991), 35.

${ }^{26}$ Barbara Kiereś, Antropologia a pedagogika, http://ien.pl/index.php/archives/1389?EsetProtoscanCtx=20f9c3505eo [dostęp: 27.04.2016].
} 
Jan Paweł II. „List Iuvenum Patris $w 100$ rocznicę śmierci św. Jana Bosko, Rzym, 31.01.1988“. W: Wychowanie w nauczaniu Jana Pawła II, red. Stanisław Urbański, 301-322. Warszawa: Wyższa Szkoła Zarządzania i Przedsiębiorczości im. Bogdana Jańskiego, 2000.

Kostkiewicz, Janina. Kierunki i koncepcje pedagogiki katolickiej w Polsce 1918 - 1939. Kraków: Oficyna Wydawnicza „Impuls”, 2013.

Maryniarczyk, Andrzej. System metafizyki. Lublin: Redakcja Wydawnictw KUL, 1991.

Maryniarczyk, Andrzej. Zeszyty z metafizyki, t. I. Lublin: Polskie Towarzystwo Tomasza z Akwinu, 2001. Maryniarczyk, Andrzej. Zeszyty z metafizyki, t. III. Lublin: Polskie Towarzystwo Tomasza z Akwinu, 1999.

Mioduszewski, Tomasz. Spór orealizm wlubelskiej szkole filozoficznej. Ząbki: APOSTOLICUM Wydawnictwo Księży Pallotynów Prowincji Chrystusa Króla, 2013.

Okoń, Wincenty. Nowy Stownik Pedagogiczny. Warszawa: Wydawnictwo Akademickie „Żak”, 1995.

Kapuściński, Ryszard. Ten Inny. Kraków: SIW Znak, 2006.

S. Thomas Aquinatis. In XII libros metaphysicorum commentarium, proemium.

Kiereś, Barbara. Antropologia a pedagogika, http://ien.pl/index.php/archives/1389?EsetProtoscanCtx=20f9c3505eo [dostęp: 27.04.2016]. 